\title{
Osteossíntese em fratura diafisária proximal em espiral de rádio em potro
}

Daniela Maria Schueroff, Frederico Fernandes Araújo; Yasmim Varago Farth, Mariana Cosenza, Ana Flavia Costa, Homero Leite

Martins, Pedro Victor Luna Freire Oliveira, Lucas Ruan Pires, Danielle Araújo Barbosa

Centro Universitário Filadélfia (Unifil), Londrina, PR, Brasil

*Autor correspondente

e-mail: fred_arj@hotmail.com

\section{Resumo}

Nos equinos, as fraturas do rádio são menos frequentes que as da ulna, sendo causadas principalmente por traumas externos. 0 diagnóstico é realizado pelo exame físico, apresentando claudicação de apoio e crepitação acompanhada de instabilidade do membro, e a avaliação radiográfica confirma a existência da fratura. A escolha do método de fixação baseia-se no tipo e localização da fratura, tamanho e idade do animal, número de ossos envolvidos e viabilidade dos tecidos moles da região. A reparação das fraturas requer redução anatômica e rígida estabilidade para que ocorra a cicatrização do osso fraturado e o paciente restabeleça as funções do membro. Foi encaminhado ao Hospital Veterinário da Unifil um potro macho, da raça Quarto de Milha, com 4 meses de idade e fratura de rádio. 0 animal chegou em pé no trailer, imobilizado com tala, porém, esta havia saído do lugar. 0 animal foi encaminhado para exame radiográfico, onde evidenciou-se uma fratura diafisária proximal em espiral no rádio. A fratura foi imobilizada e mantida assim até o momento da cirurgia. 0 animal foi encaminhado para cirurgia de osteossíntese, guiada com radiografia transoperatória. A sedação foi realizada com xilasina, a indução com cetamina associada ao diazepam e a manutenção, com isoflurano. 0 acesso realizado foi crânio-lateral com afastamento e divulsionamento da musculatura músculo extensor radial do carpo, músculo extensor digital comum para melhor visualização da fratura. Após a redução da fratura, a mesma foi estabilizada, previamente à fixação das placas, por um parafuso cortical em lag com auxílio das pinças de redução de fraturas, transfixando e estabilizando os dois fragmentos. Primeiramente, fixou-se uma placa de 4,5 mm de 10 parafusos na parte cranial do radio, fixada por 8 parafusos, e depois uma placa de 4,5 $\mathrm{mm}$ com oito furos, fixada com seis parafusos na região lateral do osso. As placas foram fixadas com parafusos corticais 4,5 mm e um parafuso esponjoso 4,5 mm. A musculatura foi reposicionada e sua parte lesionada foi suturada com padrão de Sultan, fio poliglactina 0 . 0 tecido subcutâneo foi reduzido com sutura de cushing, fio poliglactina 2,0; e a pele, com ponto simples 
contínuo, fio nylon 0 . Após a cirurgia, o membro foi imobilizado com tala lateral para que o animal pudesse se recuperar com mais segurança. A tala foi mantida por aproximadamente 40 dias. Para o tratamento pós-operatório, foi utilizada antibioticoterapia com gentamicina associada ao ceftiofur e antiinflamatório Meloxicam. Os curativos eram realizados a cada 10 dias, com a colocação de uma nova tala de alumínio. Após 20 dias, foi realizada a radiografia, onde não se observou nenhum indício de osteomielite ou qualquer rejeição aos parafusos. Outra radiografia foi realizada em 55 dias após a cirurgia, onde observou-se formação de calo ósseo com aumento de radiopacidade na linha de fratura e migração do parafuso medular. 0 animal ainda se encontra em tratamento, sem o uso de tala e apoiando o membro no solo desde o primeiro dia de pós-operatório. Foi realizada uma aproximação máxima entre os fragmentos. Na literatura, encontramos tratamentos que utilizam a fixação externa ou até mesmo o tratamento conservativo, sendo poucos os resultados encontrados sobre o sucesso da fixação com placas e parafusos em fraturas radiais em potros. Até o momento, a fixação com placas e parafusos no tratamento da fratura proximal de rádio em potro está se mostrando eficiente, com o rápido e completo restabelecimento funcional do membro.

Palavras-chave: Cirurgia ortopédica. Placa e parafuso. Equino. 